\title{
Exposure to viral and bacterial pathogens among Soay sheep (Ovis aries) of the St Kilda archipelago
}

\author{
A. L. GRAHAM ${ }^{1,2 * \dagger}$, D. H. NUSSEY ${ }^{3} \dagger$, J. O. LLOYD-SMITH ${ }^{2,4}$, \\ D. LONGBOTTOM ${ }^{5}$, M. MALEY ${ }^{5}$, J. M. PEMBERTON ${ }^{3}$, J. G. PILKINGTON ${ }^{3}$,

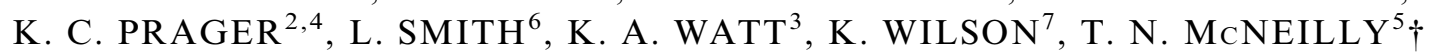 \\ AND F. BRÜLISAUER ${ }^{8 * \dagger}$ \\ ${ }^{1}$ Department of Ecology \& Evolutionary Biology, Princeton University, Princeton, NJ, USA \\ ${ }^{2}$ Fogarty International Center, National Institutes of Health, Bethesda MD, USA \\ ${ }^{3}$ Institute of Evolutionary Biology, School of Biological Sciences, University of Edinburgh, Edinburgh, UK \\ ${ }^{4}$ Department of Ecology \& Evolutionary Biology, University of California Los Angeles, Los Angeles, CA, USA \\ ${ }_{6}^{5}$ Moredun Research Institute, Pentlands Science Park, Penicuik, Midlothian, UK \\ ${ }^{6}$ Animal and Plant Health Agency, New Haw, Addlestone, Surrey, UK \\ ${ }^{7}$ Lancaster Environment Centre, Lancaster University, Lancaster, UK \\ ${ }^{8}$ SAC Consulting Veterinary Services, Scotland's Rural College, Inverness, UK
}

Received 30 September 2015; Final revision 9 December 2015; Accepted 6 January 2016; first published online 1 February 2016

\section{SUMMARY}

We assessed evidence of exposure to viruses and bacteria in an unmanaged and long-isolated population of Soay sheep (Ovis aries) inhabiting Hirta, in the St Kilda archipelago, $65 \mathrm{~km}$ west of Benbecula in the Outer Hebrides of Scotland. The sheep harbour many metazoan and protozoan parasites but their exposure to viral and bacterial pathogens is unknown. We tested for herpes viral DNA in leucocytes and found that 21 of 42 tested sheep were infected with ovine herpesvirus 2 (OHV-2). We also tested 750 plasma samples collected between 1997 and 2010 for evidence of exposure to seven other viral and bacterial agents common in domestic Scottish sheep. We found evidence of exposure to Leptospira spp., with overall seroprevalence of $6.5 \%$. However, serological evidence indicated that the population had not been exposed to border disease, parainfluenza, maedivisna, or orf viruses, nor to Chlamydia abortus. Some sheep tested positive for antibodies against Mycobacterium avium subsp. paratuberculosis (MAP) but, in the absence of retrospective faecal samples, the presence of this infection could not be confirmed. The roles of importation, the pathogenhost interaction, nematode co-infection and local transmission warrant future investigation, to elucidate the transmission ecology and fitness effects of the few viral and bacterial pathogens on Hirta.

Key words: Epidemiology, parasites.

\section{INTRODUCTION}

The species composition of an island community is expected to be shaped by both the distance of the island from the mainland (e.g. as a predictor of immigration rates) and by the area of the island (e.g. as a predictor of extinction rates) [1]. Parasites and

\footnotetext{
* Author for correspondence: Professor A. L. Graham, Department of Ecology \& Evolutionary Biology, Princeton University, 106a Guyot Hall, Princeton, NJ 08544, USA.

(Email: algraham@princeton.edu) [A.L.G.]

(Email: Franz.Brulisauer@sruc.ac.uk) [F.B.]

$\dagger$ These authors contributed equally to this work.

This is an Open Access article, distributed under the terms of the Creative Commons Attribution licence (http://creativecommons.org/licenses/by/4.0/), which permits unrestricted re-use, distribution, and reproduction in any medium, provided the original work is properly cited.
} 
pathogens, too, must immigrate and avoid extinction in order to prosper on islands. Indeed, the establishment of infectious diseases on remote islands is probably hindered by low immigration rates (especially if founder hosts arrive uninfected) and by low or variable host densities [2]. Small host populations are a particular obstacle for acute immunizing infections, for which a positive relationship between population size and pathogen persistence is expected [3] (the classic example being measles [4]). Accordingly, depauperate parasite communities have been reported on several islands compared to mainland populations [5].

Soay sheep (Ovis aries) inhabiting the island of Hirta, in the St Kilda archipelago of the Outer Hebrides of Scotland (Fig. 1), present an opportunity to study the role of parasites and pathogens in the life histories of island ruminants. Since Neolithic times, the sheep have lived on St Kilda, isolated from other Hebridean islands by $\sim 65 \mathrm{~km}$ and from dense sheep populations on the Scottish mainland by a further $\sim 60 \mathrm{~km}$. Historically, visitor traffic was minimal but it is currently rising. A few dozen people live on Hirta year-round, on a shift-work basis with trips to the mainland between shifts. The focal sheep population has been unmanaged since 1930, when 103 founders were moved to Hirta from Soay [6]. The population undergoes boom-bust dynamics, with overwinter die-offs caused by forage limitation, harsh winter weather, and parasites [7]. Known infectious agents of the sheep include an array of metazoan and protozoan parasites [8], including strongyle nematodes [9], coccidia [10], and cryptosporidia [11]. Other than the potential for transmission of trypanosomes on Hirta by ectoparasitic keds [12] which have been eliminated from domestic sheep, this represents a depauperate parasite fauna compared to sheep on the Scottish mainland (e.g. notably lacking the flatworm Fasciola hepatica) [8].

These parasites, especially the nematodes, are thought to be the most important natural enemies faced by the sheep, given the dearth of predators on Hirta. However, the role, if any, of viruses and bacteria in the ecology of this island population is unknown. Here, we report results of tests for exposure of the sheep to eight viral and bacterial infectious agents common in sheep elsewhere in Scotland. For example, in a randomized serosurvey comprising 125 Scottish flocks in $2007,32 \cdot 8 \%$ of flocks tested positive for previous exposure to border disease virus (BDV) and $96.0 \%$ to parainfluenza-3 virus (PI3 V) [13], both of which mainly cause transient infections followed by robust immunity. Furthermore, we were interested in common ovine pathogens that cause chronic infections. These included ovine herpesvirus (OHV-2), maedi-visna virus (MVV) and Chlamydia abortus, the most common infectious abortifacient in the UK [14]. Finally, we were interested in Mycobacterium avium subsp. paratuberculosis (MAP) and Leptospira spp., both of which infect a wide range of species, induce chronic carriage, and may survive in the environment for extended periods of time. Our results confirm epidemiological isolation of the Soay sheep but also suggest potential for local transmission of herpesvirus and leptospire infections, in addition to the highly prevalent nematodes and coccidia $[9,10]$.

\section{METHODS}

The sheep in the Village Bay area of the $6.3 \mathrm{~km}^{2}$ island of Hirta in the St Kilda archipelago $\left(57^{\circ} 49^{\prime}\right.$ N $/ 08^{\circ}$ $35^{\prime} \mathrm{W}$ ) have been the subject of longitudinal, individual-based demographic, genetic and phenotypic study since 1985 [6]. Each April, 95\% of lambs are tagged within a week of birth. The population is thus characterized by birth pulses, the timing of which varies modestly among years (e.g. median birth date ranged from 15 April to 25 April for lambs born between 1986 and 2000) and may reflect density-dependent demographic rates [6]. Each August, $\sim 50 \%$ of the population is re-captured, and blood samples are collected into heparin, stored at $4{ }^{\circ} \mathrm{C}$ and, within 24 $\mathrm{h}$ of collection, centrifuged at $\sim 1500 \mathrm{~g}$ for $15 \mathrm{~min}$. Plasma and cellular fractions are separated and stored at $-20^{\circ} \mathrm{C}$.

\section{Serosurvey for evidence of exposure to seven viral and bacterial infectious agents}

For our primary serosurvey across seven pathogens and 14 years, we selected 750 plasma samples for testing, using a random number generator within each age group, capture year and sex. These 750 demographically representative but otherwise randomly selected samples came from 659 individual sheep captured each August during the years 1997-2010 (Table 1) and included samples from 350 yearlings and 400 adults (aged 3-5 years), with 91 individuals sampled as both yearling and adult. We tested males and females equally. In pilot serosurveys across fewer pathogens and sampling years, we had previously commissioned tests for MVV in 196 plasma samples 

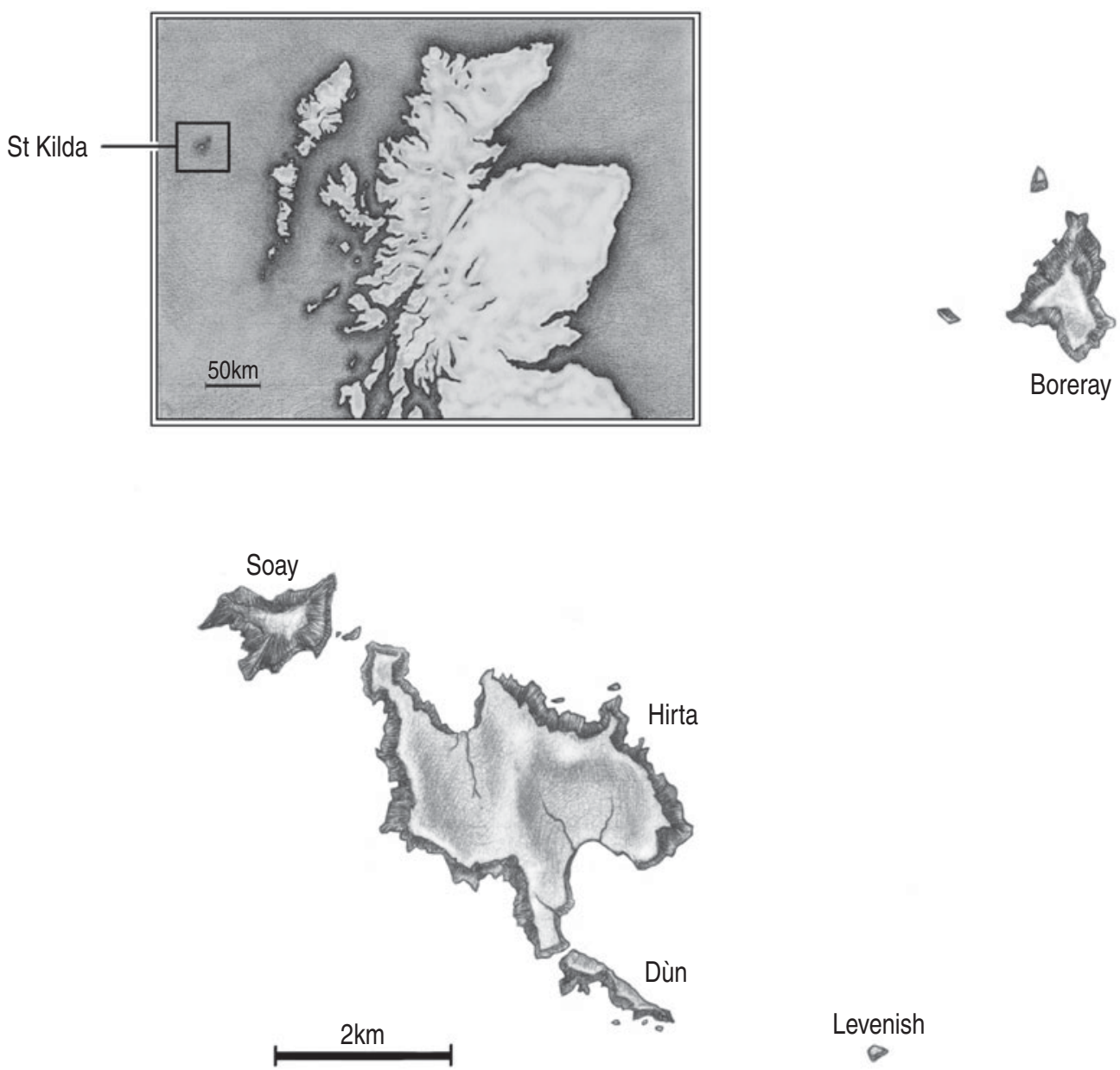

Fig. 1. Map of the St Kilda archipelago, with islands including Hirta, where the focal population of sheep live. Location of the archipelago relative to mainland Scotland is shown in the inset. (The maps were drawn by Rebecca Holland.)

collected in 1986, and for MVV, BDV, C. abortus and MAP in a separate set of 50 plasma samples collected in 2000. For each pilot and for the primary serosurvey, we distributed aliquots to governmental and commercial agencies specializing in the tests required (Table 2, with citations to detailed descriptions of all serological methods): the SAC Consulting Veterinary Services (Disease Surveillance Centres in Inverness and St Boswells), the Animal and Plant Health Agency (APHA, a division of the Department for Environment, Food and Rural Affairs; Defra), and the Moredun Research Institute (MRI).

Where possible, positive results by initial screening were followed with appropriate tests of heightened specificity. Our most detailed follow-up was for Leptospira spp. For the 43 individuals positive by generic microscopic agglutination test (MAT) at a plasma dilution of $\geqslant 1: 100$, we conducted a follow-up MAT to quantify antibodies capable of agglutinating bacteria from five candidate serovars across three species:
Leptospira interrogans serovar (sv.) Hardjo and $L$. interrogans sv. Pomona; L. borgpetersenii sv. Hardjo and $L$. borgpetersenii sv. Ballum; and L. biflexa sv. Patoc. We selected these because they could plausibly be transmitted on Hirta: the first three can be maintained within ruminant populations [15], Ballum is maintained in rodent reservoirs [16] such as the endemic Hirta mouse, and Patoc is a saprophyte [17]. We note that $L$. interrogans sv. Hardjo and $L$. borgpetersenii sv. Hardjo are the most prevalent in sheep on the Scottish mainland [18]; antibodies against them have been detected in $6 \cdot 3 \%$ of domestic sheep across England and Wales [15]. Serovar-specific MAT requires live Leptospira cultures in liquid medium. Starting with 1:50 dilution, we mixed a series of twofold dilutions of plasma (1:100, 1:200, etc.) with equal volumes of culture. After incubation at $30^{\circ} \mathrm{C}$, we read results by dark-field microscopy. The last dilution at which $>50 \%$ of bacteria remained agglutinated was reported as the endpoint titre [19]. 
Table 1. Number of sheep tested in our major serosurvey, according to age group (yearlings vs. adults, 3-5 years of age) and capture year

\begin{tabular}{lcc}
\hline \hline Sampling year & Yearlings tested & Adults tested \\
\hline 1997 & 0 & 54 \\
1998 & 0 & 23 \\
1999 & 0 & 40 \\
2000 & 42 & 23 \\
2001 & 42 & 19 \\
2002 & 0 & 15 \\
2003 & 42 & 28 \\
2004 & 42 & 32 \\
2005 & 0 & 8 \\
2006 & 22 & 26 \\
2007 & 31 & 49 \\
2008 & 43 & 19 \\
2009 & 43 & 22 \\
2010 & 43 & 42 \\
Total & 350 & 400 \\
\hline
\end{tabular}

Of the 350 yearlings tested, 91 were also tested as adults. We thus tested 750 plasma samples collected from 659 individual animals. Samples from yearlings were available from each August of years 2000-2010, except for 2002 and 2005 due to near-complete mortality of that age group over the preceding winter. Samples from adult sheep were available annually from 1997 to 2010, but with fewer samples collected following the large population die-offs (e.g. in 2002 and 2005).

We applied positivity cut-offs of 1:100 for screening and 1:50 for sensitive confirmatory testing [16].

\section{Polymerase chain reaction (PCR) of blood cells for OHV-2 detection}

For OHV-2 testing, DNA was extracted from the leukocyte fraction of blood for 42 animals caught in 2010. Initially, we used OHV-2-specific real-time PCR [20], but no samples were positive by this method. Therefore, we performed nested panherpesvirus consensus PCR [21] using a mix of degenerate and deoxyinosine-substituted primers (primary PCR: forward primers DFA and ILK, and reverse primer KG1; secondary PCR: forward primer TGV and reverse primer IYG) and HotStarTaq (Qiagen, UK). The thermal cycling conditions for both PCRs consisted of an initial activation step of $95^{\circ} \mathrm{C}$ for 15 min, then 45 cycles of $30 \mathrm{~s}$ denaturation at $95^{\circ} \mathrm{C}, 1$ min of annealing at $46{ }^{\circ} \mathrm{C}$ and $1 \mathrm{~min}$ of strand extension at $72{ }^{\circ} \mathrm{C}$, followed by a final extension step of 10 min at $72{ }^{\circ} \mathrm{C}$. Amplicons were detected by electrophoresis in $1.5 \%$ agarose/TAE gel followed by staining with SYBR Safe DNA Gel Stain (Invitrogen, UK) and ultraviolet transillumination. Specific PCR products of $231 \mathrm{bp}$ obtained from 21 of the samples were purified using ChargeSwitch PCR Clean-Up kit (Invitrogen) and sequenced in both directions using the primers TGV and IYG (Eurofins Genomics, UK). Sequences were obtained from 18 of these 21 samples. We assembled sequences using DNAStar (USA) and compared 178 bp sequences within primer sites to published data with a BLAST search (http:// blast.ncbi.nlm.nih.gov/Blast.cgi).

\section{Statistical analysis of serological responses to Leptospira spp.}

We analysed predictors of seropositivity (a binary variable reflecting whether an individual had an MAT titre that exceeded the positivity cut-off) using $\mathrm{R}$ v. 3.1.1 (https://cran.r-project.org/bin/windows/ base/old/3.1.1/). First, we analysed predictors of seropositivity separately within each age group. We fitted a binomial error distribution and specified a logit link function. We included sex and years of birth and capture as fixed effects. Model variants were considered to improve fit if log-likelihood (LL) improved in likelihood ratio tests (LRTs), with the $\chi^{2}$ test statistic calculated as $-2 *\left(\mathrm{LL}_{\text {model } 2}-\mathrm{LL}_{\text {model1 }}\right)$. The significance of changed LL between models was assessed using $P$ values based on that $\chi^{2}$ statistic on 1 degree of freedom. Because of the small number of positives, we used exact logistic regression in the package elrm [22] to confirm and quantify predictors of seropositivity. Next, we analysed predictors of seropositivity in the 91 individuals tested both as yearlings and as adults, using linear mixed-effects models with a fixed effect of host sex and random effects of year of each capture (i.e. as yearling and as adult) and individual identity. Significance was determined using LRT, and results for the binary predictor of sex were confirmed with the non-parametric $\varphi$ coefficient of association (to quantify the strength of association between sex and seropositivity) and Fisher's exact tests (to compute a test statistic and $P$ value for that association).

\section{RESULTS}

\section{No viral exposure detectable by serosurvey}

We found no convincing evidence of exposure to viral pathogens by serosurvey. No samples from the 400 
Table 2. (a) Viral and (b) bacterial infectious agents for which samples were tested, and number and percentage positive for these agents, across all sheep and years tested in our major survey

\begin{tabular}{|c|c|c|c|}
\hline Infectious agent & Taxon, tissue affected & Method, tester, ref. & $\begin{array}{l}\text { No. positive/ } \\
\text { no. tested }(\%)\end{array}$ \\
\hline \multicolumn{4}{|l|}{ (a) Viruses } \\
\hline Border disease virus (BDV) & $\begin{array}{l}\text { Pestivirus of intestinal and urogenital } \\
\text { tracts }\end{array}$ & ELISA [32], MRI & $0 / 400(0 \%)$ \\
\hline Parainfluenza-3 virus (PI3 V) & Paramyxovirus of respiratory tract & ELISA [33], MRI & $0 / 400(0 \%)$ \\
\hline Orf virus & Parapoxvirus of skin & ELISA, MRI & $0 / 400(0 \%)$ \\
\hline Maedi-visna virus (MVV) & $\begin{array}{l}\text { Lentivirus of immune and respiratory } \\
\text { systems }\end{array}$ & $\begin{array}{l}\text { ELISA [16], AGID [24], } \\
\text { SACCVS* }\end{array}$ & $0 / 659(0 \%)$ \\
\hline $\begin{array}{l}\text { Ovine herpes virus- } 2 \\
\text { (OHV-2) }\end{array}$ & Herpesvirus affecting lymphocytes & PCR [21], MRI & $21 / 42(50 \%)$ \\
\hline \multicolumn{4}{|l|}{ (b) Bacteria } \\
\hline $\begin{array}{l}\text { Agent of ovine chlamydial } \\
\text { abortion }\end{array}$ & $\begin{array}{l}\text { Chlamydia abortus, uterine and placental } \\
\text { epithelium }\end{array}$ & $\begin{array}{l}\text { CFT [16], ELISA [27], } \\
\text { SACCVS, MRI* }\end{array}$ & $0 / 659(0 \%)$ \\
\hline Agent of Johne's disease & $\begin{array}{l}\text { Mycobacterium avium subsp. } \\
\text { paratuberculosis, intestine }\end{array}$ & ELISA [16], SACCVS & $8 \dagger / 659(1 \cdot 2 \% \dagger)$ \\
\hline Agent of leptospirosis & Leptospira spp., primarily urogenital tract & MAT [16], APHA & $43 / 659(6 \cdot 5 \%)$ \\
\hline
\end{tabular}

The table includes the taxonomic identity of each infectious agent, tissues affected, detection methods [enzyme-linked immunosorbent assay (ELISA); agar gel immuno-diffusion (AGID); polymerase chain reaction (PCR); complement fixation test (CFT); or microscopic agglutination test (MAT)] and testing agencies [Moredun Research Institute (MRI); SAC Consulting Veterinary Services (SACCVS) Disease Surveillance Centres (DSC) at Inverness and St Boswells; or Animal and Plant Health Agency (APHA)]. The final column shows results in terms of the number (and percentage) of individual sheep positive out of the number tested.

* Denotes two ELISA and 32 CFT positive samples that were then determined to be false positives by AGID for MVV [24] and POMP-specific ELISA for C. abortus [27].

$\dagger$ Denotes ELISA positives but we could not undertake MAP bacterial culture to confirm whether these were true positives.

adult sheep contained detectable antibodies against BDV, PI3 V or orf virus (Table 2). We therefore did not test yearlings for these infections. We did detect antibodies against MVV in two adult sheep by ELISA. The samples exhibited optical densities (ODs) of 0.589 and 0.826 , in relation to a negative cutoff of 0.231 and a MVV positive control of 0.776 . However, 2/400 is within the false-positive rate for the test [23], and of the 350 samples from yearlings, none had detectable antibodies. At follow-up testing of the two putative positive adult samples by the more specific agar gel immuno-diffusion (AGID) assay [24], the positive results were not confirmed. These results of our major serosurvey are summarized in Table 2. Furthermore, the pilot serosurveys of 196 plasma samples collected in 1986 were negative for $\mathrm{MVV}$, and the 50 samples tested in 2000 were negative for both MVV and BDV.

\section{Viral infection detectable by PCR of white blood cells}

Initial analysis of white blood cell fractions from 42 sheep using OHV-2-specific primers in a real-time
PCR assay [20] were negative. However, subsequent nested PCR using 'pan-herpesvirus' primers [21] revealed that 21 sheep were positive (Table 2); 18 contained OHV-2 DNA sequences, with results of insufficient quality for analysis in the other three samples. All 18 sequences were $100 \%$ identical to each other and $99-100 \%$ identical to published sequence for OHV-2 across the 178 bp region. Failure of the realtime PCR suggests low viraemia, consistent with previous suggestions that it may not be sensitive enough to detect OHV-2 DNA in sub-clinically infected animals [25].

\section{Bacterial exposure detectable by serosurvey}

Of the 400 adults, four were weakly positive for $C$. abortus; in the yearlings, 28 came up weakly positive (at plasma dilutions 2-4/32). Similarly, for the separate sample set from the pilot serosurvey in 2000, $1 / 50$ sheep was weakly positive (at 2/32) for this agent. Cross-reactivity between $C$. abortus, nonpathogenic enteric $C$. pecorum strains, and environmental bacteria such as Acinetobacter spp. can give 
rise to low false-positive results by this complement fixation test [26]. The low titres and the unexpected association with yearlings led us to suspect these were false positives. Indeed, follow-up tests on samples from our major serosurvey, using a C. abortus-specific indirect ELISA for antibodies against one of the polymorphic membrane proteins, POMP90 [27], showed that all 32 putative positive samples in our screening were actually negative (Table 2).

Of the 400 adults, six had detectable antibody against MAP; in 350 yearlings, two other animals were positive. Correcting for repeated sampling of 91 MAP seronegatives generated an overall seroprevalence estimate of $1 \cdot 2 \%$ (Table 2). None of the 50 samples tested in the pilot serosurvey in 2000 were positive for antibody to MAP. No seropositive sheep in our major serosurvey died within a year of the observed seropositivity; indeed, some lived a further $\geqslant 8$ years. These observations would not be consistent with the course of clinical disease in MAP-infected domestic sheep [28], and the test is of imperfect specificity (98\% [29]). However, the OD values for three of the eight positive samples exceeded the positive control, and several of the annual seroprevalences were well in excess of the expected false-positive rate (e.g. $>10 \%$ seroprevalence in $2008 ; 7 \%$ in 2010). Unfortunately, we were not able to confirm our results using PCR or cultures because no suitably preserved faecal samples were available.

By contrast, we did obtain evidence of exposure of the sheep to leptospires. Of 400 adults, 28 had antibodies at a titre of $\geqslant 100$ at screening (i.e. detectable in $\mathrm{a} \geqslant 1: 100$ plasma dilution); 16 of the 350 yearling samples were positive by these criteria. The seropositives included one individual sampled as both a yearling and an adult. We thus found an overall individual-level (as opposed to sample-level) seroprevalence of $43 / 659$, or $6.5 \%$, across all years sampled (Table 2).

Upon more sensitive testing, many of the seropositives exhibited significant titres to $L$. interrogans sv. Hardjo or L. borgpetersenii sv. Hardjo: 15 adults and 13 yearlings exceeded the titre of 50 considered a firm positive for those serovars in the more sensitive follow-up assays [16]. When we determined the sero$\operatorname{var}(\mathrm{s})$ against which sheep exhibited maximum titres (following [30]), our data suggested that L. borgpetersenii sv. Hardjo may be most prevalent in this population. We found that 13 sheep exhibited titres of up to 200 against $L$. interrogans sv. Hardjo, but it was never the maximal titre for a sheep, while 34 sheep exhibited titres up to 1600 against L. borgpetersenii sv. Hardjo, and that serovar represented the maximum titre for 21 of the sheep. However, 40 sheep also exhibited positive titres up to 200 against L. biflexa sv. Patoc, and Patoc was the maximum or joint maximum titre (most often with L. borgpetersenii sv. Hardjo) in 31 sheep. Six sheep exhibited detectable titres against L. interrogans sv. Pomona (with titres up to 100), and Pomona was joint maximum only once (at a titre of 50 along with both L. biflexa sv. Patoc and $L$. borgpetersenii sv. Hardjo). Finally, only two sheep exhibited detectable titres against $L$. borgpetersenii sv. Ballum, and Ballum was never a maximum titre. In all, 34 samples had antibodies against one or more serovars; most singlets had antibodies against only L. biflexa sv. Patoc (six at titres of 100-200). Only one sample that originally screened positive subsequently had no detectable titres. The individual male who was positive both as yearling (in 2004) and adult (in 2006) bore antibodies against $L$. biflexa sv. Patoc on both occasions (titres of 100). It should be noted that bacterial isolates will be needed to identify the circulating serovar(s) definitively.

\section{Predictors of seropositivity for leptospires}

We detected a significant temporal trend in seropositivity against leptospires in adult sheep. The full model suggested that, over the period 1997-2010, there was a significant increase in the proportion seropositive $\left(\chi_{1}^{2}=4 \cdot 3, P=0 \cdot 039\right)$, and this finding was confirmed by exact logistic regression (odds ratio across years, $\mathrm{e}^{\beta}=1 \cdot 11,95 \%$ confidence interval $1 \cdot 01$ $1 \cdot 25, P=0 \cdot 016$; Fig. 2). Host sex was not significantly associated with seropositivity of adults $\left(\chi_{1}^{2}=1 \cdot 9, P=\right.$ $0 \cdot 17$ ), and we found no significant associations of year or sex with seropositivity of yearlings (all $\chi_{1}^{2}<$ $0 \cdot 05, P>0 \cdot 81)$.

Longitudinal analysis of the 91 individuals sampled both as yearlings and as adults suggested associations of seropositivity with sex and year of adult capture. One individual (a ram) was positive at both captures, and 12 individuals seroconverted between captures. Year of adult capture $\left(\chi_{1}^{2}=17, P<0.0001\right)$ and a fixed effect of $\operatorname{sex}\left(\chi_{1}^{2}=4 \cdot 2, P=0 \cdot 040\right)$ significantly predicted seropositivity. A $\varphi$ coefficient of association test, suited to assessment of association between binary variables in a small dataset and corrected for the number of individuals (91) rather than observations (182), confirmed that males were more likely than females to seroconvert between yearling and adult 


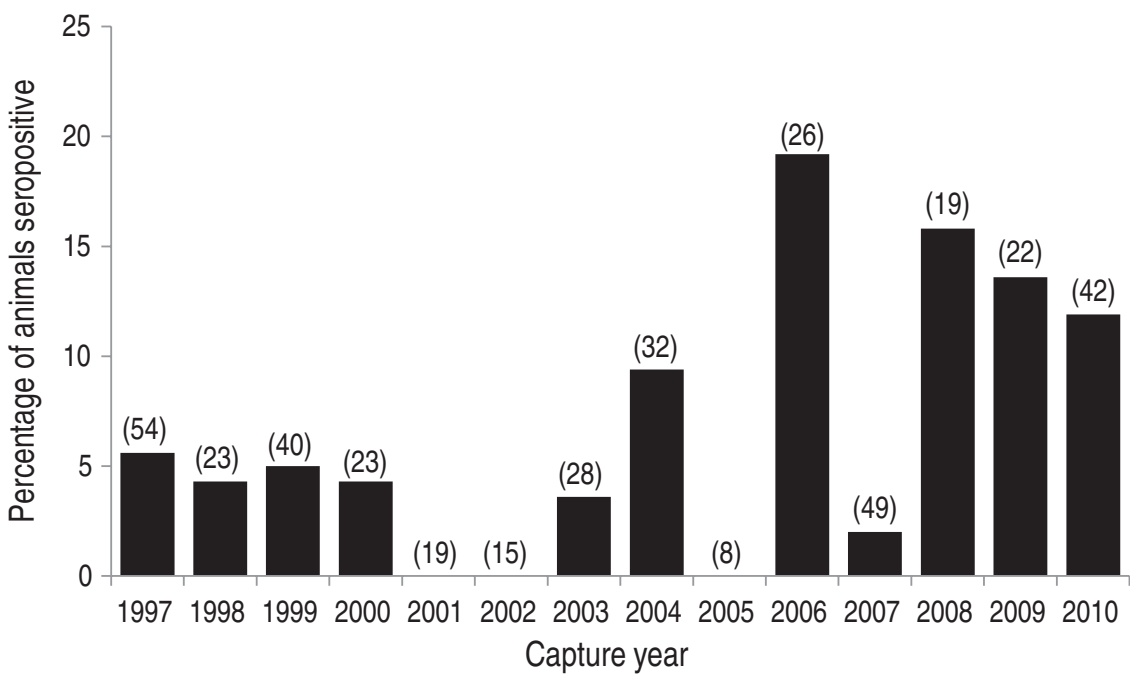

Fig. 2. Annual seroprevalence of antibodies against Leptospira interrogans sv. Hardjo and L. borgpetersenii sv. Hardjo in 400 adult Soay sheep (aged 3-5 years) sampled during 1997-2010. A sample was considered seropositive at screening if it exhibited a titre of $\geqslant 100$ by microscopic agglutination test (MAT) against live bacteria. The number of adults sampled per year is shown in parentheses above each bar; no individual sheep was sampled more than once as an adult. For several years in the time series, very few samples were available due to population die-off the preceding winter. There was a significant increase in seroprevalence with time (see text).

stages $\left(\varphi=0 \cdot 27\right.$, for $\chi_{1}^{2}=6 \cdot 6$ and Fisher's exact $P=$ $0 \cdot 016$; Fig. 3). There was no difference between sexes in the interval between samples.

\section{DISCUSSION}

We found evidence of exposure of the Soay sheep on Hirta only to the persistent and/or non-immunizing infections from this list, and to just a subset of those (Table 2). While serological testing cannot prove the absence of a pathogen beyond doubt, consistently negative results provide good evidence for freedom from infection. For example, our results are adequate to conclude that the population is free from MVV at the expected minimum prevalence of $0 \cdot 2 \%$ and at the 0.9965 confidence level; this freedom-from-disease analysis assumes test sensitivity of 0.90 and specificity of 0.99 [31]. Furthermore, for readily transmitted and strongly immunizing viruses such as BDV, PI3 V and orf virus, given the sensitivity and specificity of these tests $[32,33]$ and the high transmissibility of these infections (e.g. [34]), the consistently negative results over a decade of sampling are suggestive of freedom from infection for these three viral agents as well. The apparent absence of these infections from the Soay sheep of St Kilda contrasts with a Scotlandwide, 2007 serosurvey for BDV, PI3 V and MVV in 125 sheep flocks, including tests of 27 ewes from each of 50 flocks (and a total of 1350 ewes) in the
Highlands and Islands. That study revealed seroprevalences of up to $20 \%$ for BDV, nearly $100 \%$ for PI3 V, and up to $10 \%$ for MVV [13]. The total sample size of 659 Soay sheep in our major serosurvey (with up to 85 individuals from the 'flock' tested per year) was powered to detect such seroprevalences. We therefore suggest that more exhaustive sampling would probably not have yielded seropositives in the years sampled.

By contrast with the acute immunizing infections discussed above, pathogens such as $C$. abortus cause chronic infections and can be maintained despite low incidence and prevalence. Nonetheless, we found no convincing evidence to suggest exposure to this pathogen in the sampled Soay sheep. MAP also causes persistent infection, and we found low seroprevalence by ELISA $(<2 \%$ across years, although seroprevalence was $>10 \%$ in 2008 and $>7 \%$ in 2010). However, we were not able to undertake confirmatory culture of faeces. The presence of MAP among Soay sheep on St Kilda therefore remains to be determined.

We did find evidence of exposure to other pathogens associated with chronicity and/or subclinical carriage in domesticated Scottish sheep. For example, we detected OHV-2 DNA within circulating leukocytes of $50 \%$ of sheep tested. Further sampling and sequence analysis that targets polymorphic regions of the OHV-2 genome would be necessary to investigate long-term prevalence and genetic origins of herpes infecting St Kilda Soay sheep. It could be of interest 


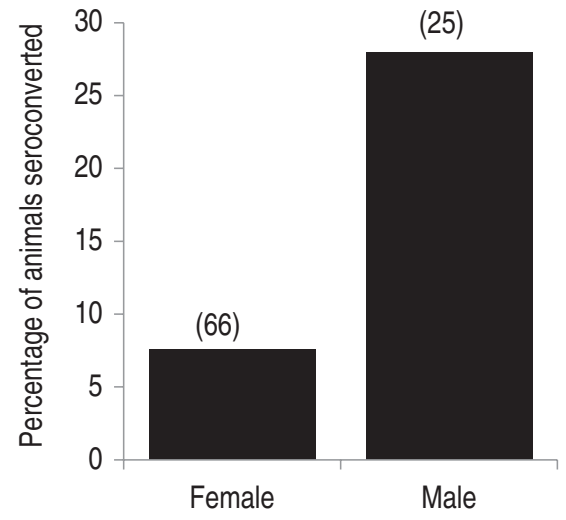

Fig. 3. Seroconversion against leptospires between yearling and adult age groups, by sex, for 91 sheep sampled both as a yearling and an adult. A sample was considered seropositive if it exhibited a titre $\geqslant 100$ by microscopic agglutination test at screening. The number of individuals longitudinally sampled per sex is shown in parentheses above each bar. A significantly greater proportion of males seroconverted (see text).

to compare their herpes to herpes in related/ancestral sheep breeds.

We also found that, in some years, seropositivity against leptospires approached 20\% (Fig. 2), which raises questions about the identity of the serovar(s) and variation in the frequency and route(s) of transmission. Most Leptospira spp. can circulate among various host species. However, leptospires cause chronic, subclinical infections only in 'maintenance' or 'reservoir' hosts. For example, Hardjo serovars circulate among ruminants, often with cattle as the reservoir [15]. Ballum, by contrast, infects sheep but uses rodents as reservoirs [16]. When reservoir hosts are removed from a community, transmission to nonreservoir hosts should fall to zero. Given that cattle have been absent from Hirta since 1930 [6], our results suggest that an ovine population might indeed be capable of maintaining transmission for the L. borgpetersenii Hardjo serovar [35]. However, there are limitations to leptospire-specific serology. For example, the sensitivity of MAT can be as low as $40 \%$, even when clinical signs and urinary excretion of bacteria are observed [36]. Definitive serovar identification and prevalence estimation on Hirta would thus require isolation of bacteria from urine of sheep and the endemic mouse species (Apodemus sylvaticus hirtensis [37]). It should be noted that government and other officials make vigorous efforts to monitor for rats, especially after any shipwrecks near Hirta; all lines of evidence to date suggest that the island remains rat free.
Conservation or management concerns become paramount when immunologically naive island inhabitants are exposed to mainland parasites (e.g. canine distemper virus purportedly in island foxes [38] or ocelots [5]). This study suggests that the sheep on St Kilda experience a wider variety of chronic, endemically transmitted infections than previously appreciated $[8,39]$ and raises many new questions about both inter-individual and inter-annual variation in the dynamics of infection. For example, resistance against nematodes is associated with improved survival of the Soay sheep [40], and effects of nematodes on host condition appear independent of coccidian co-infection [39]. But how might herpes or pathogenic Leptospira co-infection affect survival, fecundity or immunosenescence of Soay sheep? And would any of the cross-reactive antibody types detected in the sheep (e.g. autoantibodies, natural antibodies and/or IgM [40]) confer protection against these infections? Furthermore, how might the $\sim 10$-day variation in median birth date [6] and other demographic or environmental sources of inter-annual variation affect transmission dynamics? We look forward to discovering answers to these questions.

Empirical tests have borne out predictions of island biogeography [1] in several host-parasite systems (e.g. [5]). Here, we report that Soay sheep of St Kilda also harbour depauperate pathogen communities. Our findings accord with the ecological expectation that acute immunizing infections could not persist [3] on Hirta. The power of this system is that, thanks to the long-term study of the sheep [6], we can now begin to investigate the demographic consequences to the sheep of harbouring the few pathogens and parasites with life histories that enable persistence on their windswept island.

\section{ACKNOWLEDGEMENTS}

We thank the National Trust for Scotland and Scottish Natural Heritage for permission to work on St Kilda, and the Royal Artillery Range (Hebrides) and QinetiQ for logistical support. We thank T. Clutton-Brock, B. T. Grenfell and many field volunteers for enabling the project and helping to collect the samples, and Fiona Murray, Fiona Munro, Fiona Burns, and Morag Livingstone for laboratory tests. R. Garnier and A. D. Hayward provided helpful comments on the draft manuscript, and R. Holland kindly drew the maps. 
This work was supported by the U.K. Natural Environment and Biotechnology \& Biological Sciences Research Councils (including BBSRC Fellowships to A.L.G. and D.H.N.), the Wellcome Trust, and the Research and Policy for Infectious Disease Dynamics (RAPIDD) program of the Science and Technology Directorate, U.S. Department of Homeland Security, and the Fogarty International Center of the National Institutes of Health.

\section{DECLARATION OF INTEREST}

None.

\section{REFERENCES}

1. MacArthur RH, Wilson EO. The Theory of Island Biogeography. Princeton, NJ: Princeton University Press, reprinted 2001 edn. 1967, pp. 203.

2. McCallum H, Barlow N, Hone J. How should pathogen transmission be modelled? Trends in Ecology and Evolution 2001; 16: 295-300.

3. Lloyd-Smith JO, et al. Should we expect population thresholds for wildlife disease? Trends in Ecology and Evolution 2005; 20: 511-519.

4. Black FL. Measles endemicity in insular populations: Critical community size and its evolutionary implication. Journal of Theoretical Biology 1966; 11: 207-211.

5. Franklin SP, et al. Ocelots on Barro Colorado Island are infected with Feline Immunodeficiency Virus but not other common feline and canine viruses. Journal of Wildlife Diseases 2008; 44: 760-765.

6. Clutton-Brock TH, Pemberton JM (eds). Soay Sheep: Dynamics and Selection in an Island Population. Cambridge: Cambridge University Press, 2004, pp. 396.

7. Coulson T, et al. Age, sex, density, winter weather, and population crashes in Soay sheep. Science 2001; 292: 1528-1531.

8. Wilson K, et al. Parasites and their impact. In: CluttonBrock TH, Pemberton JM, eds. Soay Sheep: Dynamics and Selection in an Island Population. Cambridge: Cambridge University Press, 2004, pp. 113-165.

9. Craig BH, Pilkington JG, Pemberton JM. Gastrointestinal nematode species burdens and host mortality in a feral sheep population. Parasitology 2006; 133: 485-496.

10. Craig BH, et al. Epidemiology of parasitic protozoan infections in Soay sheep (Ovis aries L.) on St Kilda. Parasitology 2007; 134: 9-21.

11. Connelly L. et al. Genetic diversity of Cryptosporidium spp. within a remote population of Soay sheep on St. Kilda Islands, Scotland. Applied and Environmental Microbiology 2013; 79: 2240-2246.

12. Gibson W, Pilkington JG, Pemberton JM. Trypanosoma melophagium from the sheep ked Melophagus ovinus on the island of St Kilda. Parasitology 2010; 137: 17991804.
13. Clark D, Brülisauer F. Mapping the prevalence of JSRV and other endemic infections. Inverness: Scottish Government, 2008, pp. 1-25.

14. Animal and Plant Health Agency. veterinary investigation diagnosis analysis report 2012. UK Government, 2014 (https://www.gov.uk/government/statistics/veterinaryinvestigation-diagnosis-analysis-vida-report-2012).

15. Hathaway SC, Wilesmith JW, Little TW. Some population parameters of Leptospira interrogans serovar hardjo infection in sheep. Veterinary Record 1984; 114: 428-429.

16. National Veterinary Service Laboratories. Microtitre technique for detection of Leptospira antibodies. Proceedings of the U.S. Animal Health Association 1987: 91: 65-73.

17. Faine S, Stallman ND. Amended descriptions of the genus Leptospira Noguchi 1917 and the species L. interrogans (Stimson 1907) Wenyon 1926 and L. biflexa (Wolbach and Binger 1914) Noguchi 1918. International Journal of Systematic Bacteriology 1982; 32: 461-463.

18. Cousins DV, et al. Evidence for sheep as a maintenance host for Leptospira interrogans serovar hardjo. Veterinary Record 1989; 124: 123-124.

19. Goris MG, Hartskeerl RA. Leptospirosis serodiagnosis by the microscopic agglutination test. Current Protocols in Microbiology 2014; 32: 5.

20. Hussy D, et al. Quantitative fluorogenic PCR assay for measuring ovine herpesvirus 2 replication in sheep. Clinical and Diagnostic Laboratory Immunology 2001; 8: $123-128$.

21. Ehlers B, et al. Detection of new DNA polymerase genes of known and potentially novel herpesviruses by PCR with degenerate and deoxyinosine-substituted primers. Virus Genes 1999; 18: 211-220.

22. Zamar D, McNeney B, Graham J. elrm: Software implementing exact-like inference for logistic regression models. Journal of Statistical Software 2007; 21: 1-18.

23. Brinkhof $\mathbf{J}$, van Maanen $\mathbf{C}$. Evaluation of five enzymelinked immunosorbent assays and an agar gel immunodiffusion test for detection of antibodies to small ruminant lentiviruses. Clinical and Vaccine Immunology 2007; 14: $1210-1214$

24. Keen J, Kwang J, Rosati S. Comparison of ovine lentivirus detection by conventional and recombinant serological methods. Veterinary Immunology and Immunopathology 1995; 47: 295-309.

25. Traul DL, et al. Validation of nonnested and real-time PCR for diagnosis of sheep-associated malignant catarrhal fever in clinical samples. Journal of Veterinary Diagnostic Investigation 2007; 19: 405-408.

26. Jones GE, et al. Comparison of five tests for the detection of antibodies against chlamydial (enzootic) abortion of ewes. Veterinary Record 1997; 141: 164-168.

27. Longbottom D, et al. Serological diagnosis of ovine enzootic abortion by enzyme-linked immunosorbent assay with a recombinant protein fragment of the polymorphic outer membrane protein POMP90 of Chlamydophila abortus. Journal of Clinical Microbiology 2002; 40: 4235-4243. 
28. Stabel JR. Transitions in immune responses to $M y c o-$ bacterium paratuberculosis. Veterinary Microbiology 2000; 77: 465-473.

29. Clark DL, et al. Detection of Mycobacterium avium subspecies paratuberculosis: comparing fecal culture versus serum enzyme-linked immunosorbent assay and direct fecal polymerase chain reaction. Journal of Dairy Science 2008; 91: 2620-2627.

30. Lloyd-Smith JO, et al. Cyclical changes in seroprevalence of leptospirosis in California sea lions: endemic and epidemic disease in one host species? $B M C$ Infectious Diseases 2007; 7: 125.

31. Cameron AR, Baldock FC. A new probability formula for surveys to substantiate freedom from disease. Preventive Veterinary Medicine 1998; 34: 1-17.

32. Fenton A, et al. A monoclonal antibody capture ELISA to detect antibody to border disease virus in sheep serum. Veterinary Microbiology 1991; 28: 327-333.

33. Adair BM, et al. Survey for antibodies to respiratory viruses in two groups of sheep in Northern Ireland. Veterinary Record 1984; 115: 403-406.

34. Lehmkuhl HD, et al. Seroepidemiologic survey for antibodies to selected viruses in the respiratory tract of lambs. American Journal of Veterinary Research 1985; 46: 2601-2604.

35. Gerritsen MJ, et al. Sheep as maintenance host for Leptospira interrogans serovar hardjo subtype hardjobovis. American Journal of Veterinary Research 1994; 55: 1232-1237.

36. Thiermann AB. Bovine leptospirosis: bacteriologic versus serologic diagnosis of cows at slaughter. American Journal of Veterinary Research 1983; 44: 2244-2245.

37. Elton C. Metazoan parasites from mice in Isle of Lewis, Outer Hebrides. Parasitology 1934; 26: 107-111.

38. Timm SF, et al. A suspected canine distemper epidemic as the cause of a catastrophic decline in Santa Catalina Island foxes (Urocyon littoralis catalinae). Journal of Wildlife Diseases 2009; 45: 333-343.

39. Craig BH, et al. Metazoan-protozoan parasite coinfections and host body weight in St Kilda Soay sheep. Parasitology 2008; 135: 433-441.

40. Nussey DH, et al. Multivariate immune defences and fitness in the wild: complex but ecologically important associations among plasma antibodies, health and survival. Proceedings of the Royal Society of London B, Biological Sciences 2014; 281: 20132931. 